\title{
An Empirical Investigation on the Effect of Image Differentiation on Service Delivery of Selected Insurance Firms in Nairobi City County, Kenya
}

\author{
Benadette Kemboi Kiprono*, Godfrey Muigai Kinyua \\ School of Business, Kenyatta University, Nairobi, Kenya
}

*Corresponding Authors: Benadette Kemboi Kiprono, School of Business, Kenyatta University, Nairobi, Kenya

\begin{abstract}
The study sought to investigate role of image differentiation on service delivery of insurance firms in Nairobi City County, Kenya. Image differentiation was measured in terms of brand image, company logos and symbols as well as known personality brand. On the other hand, service delivery was operational zed as turnaround times, customer feedback, assurance of quality and responsiveness to customer needs. The research adopted the descriptive survey design. The study targeted a population of 338 managers comprising of middle level managers, functional managers and functional staff. Stratified sampling design was used to arrive at a sample size of 100 respondents. The collection of research data was done using structured questionnaire and also Likert scale. Quantitative data were analyzed using SPSS to get inferential and descriptive statistics. The presentation of the output results was done through figures, tables and graphs. Simple linear regression analysis was run to ascertain the degree of association between the dependent and independent variables. Findings established image differentiation had positive and significant effect on service delivery. It was recommended that insurance companies should conduct regular surveys and encourage customer feedback to assess the perception the public have on their firm.
\end{abstract}

Key words: Image Differentiation, and Service Delivery

\section{INTRODUCTION}

Insurance firms across the globe face the pressure associated with high competition and demands from clients who want customized services to suit their specific needs. It is however a difficult task trying to measure the productivity of the insurance sector. Al Khattab and Aldehayyat (2014), report that the average life and non-life insurance subscription by the average Indians is low and don't meet the required threshold. The competitive environment has been escalating forcing insurance firms to develop and employ optional delivery channels. For a firm to survive and succeed, it ought to engage in creation and maintenance of a match between its core strategy and the surrounding environment, as well as between its internal capacity and its strategy.

Insurance service providers embark on creativity and marketing innovation to remain relevant in the very competitive market and gain competitive advantage. Speed and time, contributes immensely to success in service delivery, providers who are effective in them attain competitive advantage and amass good satisfactory number of clients who are loyal to the organization. Customers don't compromise on their need for better quality services as most clients know innumerable alternatives offering standard of services (Alabar, Egena \& Gbande, 2014). Firms prefer to maintain the relationship they have with their existing customers than risking getting new ones.

According to Shafiwu and Mohammed (2013), the costs involved in attracting new clients is six time more compared to retaining the existing ones. Insurance firms need to adopt assess their image differentiation to ensure clients have a positive perceived image of their firm, which increases loyalty and rise the number of people buying insurance. There is need to increase differentiation of key products offered by insurance firms together with improving peoples' lives by cushioning them against impacts of risks in the dynamic world (Kamau, 2013). Turnaround times, knowledge of market needs, customer feedback, responsiveness to customer needs, assurance of quality service expectations and experience were all indicators used to measure service delivery of insurance firms. 
Exiting literature demonstrate that stakeholder participation, transparency, customer feedback employee capacity could be used to evaluate service delivery of firms (Mwakanyeza, Kwandanyi \& Ikobe, 2013; Al Khattab, 2014; Farshid \& Amir, 2014). Service delivery, occurs in components that include service environment, contact personnel and finally client component (Brown, 2013). Client satisfaction arising from good client service has become a corporate priority as it contributes to corporate's positive image. Other

Image differentiation refers to customers' perception of both the image and brand of an organization, and the way the organization appeal to customers (Barney \& Hesterly, 2013) Distinctive/strong image, known personality brand and company logo/symbols indicators were used to measure image differentiation of the insurance firms. Selected Insurance firms in Nairobi City County strive to maintain customers' positive anticipations and outcomes to ensure clients get good experiences. However, since service delivery is approached from various dimensions such as customer service, quality of service, turnaround times, among others, the research done on each of these has revealed a discrepancy on each of them. A report by AKI (2017), showed insurance firms in Nairobi City County as underperforming, despite the high number of fees they charge their clients. This creates a service gap in the insurance industry in Nairobi as most of the insurance service providers have not yet embraced Image differentiation strategies to improve their service delivery and performance.

The findings from some of the previous studies conducted on image differentiation and service delivery suffer from a variety of research gaps. For instance, Kamau (2013) found out that insurance companies that lacked differentiation strategies experience low market penetration. Equally, Kiragu (2014) concluded that image differentiation had a positive effect on competitive advantage of insurance companies in Kenya. Even though the two studies were carried out in the insurance industry, the focus was not on service delivery. Similarly, Mashruwala and Tripathy (2014) found out that image differentiation critically affected the performance of organizations. This study however was not confined to the insurance industry and thus there is need to validate the conclusion by undertaking replicative studies in the insurance industry. This study therefore, investigated the effect of image differentiation on service delivery on selected Insurance companies in Nairobi City County, Kenya.

\section{LITERATURE REVIEW}

\subsection{Michael Porter's Competitive Forces Theory}

Michael Porter developed the model in 2008. The main five forces captured in the theory include buyers' purchasing power, suppliers' bargaining power, threat to substitutes offered by suppliers, threat to entry into the market, and fierce rivalry between competitors. Porter holds that the basis for proper development of a strategy lies in the understanding of the forces that shape the competition of a sector. According to Porter, generic differentiation strategies like image differentiation strategies can be correlated effectively to a firm's service delivery by employing various alternative strategic practices. Porter contends that in situations where forces are extreme, none of the firms will be able to earn desirable returns on investment and in case the forces are begin, majority of the firms are profitable. By insurance firms adopting an image differentiation strategy, they are able to acquire a competitive strategy against their competitors. Image differentiation strategies are conventionally recognized as a strategy typology for majority of firms. The Michael Porter's model has emerged to become a powerful instrument for methodically diagnosing the major competitive pressures in the market as well as assessing how significant and strong each one is.

The relationship between Porter's five forces and image differentiation is that the latter aims at the wider market that incorporates creating a unique product or service that would stand out in the entire industry, making clients develop a positive image about the firms. Firms in the industry may opt to differentiate their image in a variety of methods including network clientele service, dealers, design, brand image, new technology and other combined features. With image differentiation strategies in place, Porter's five forces will enable a firm to deal with increasing price rises in product and service, frequent changes in clientele tastes and preferences and competitor threats owing to additional costs that are involved in addition of unique product features meant to achieve desirable success in their service delivery efforts. 
An Empirical Investigation on the Effect of Image Differentiation on Service Delivery of Selected Insurance Firms in Nairobi City County, Kenya

Through Porter's Model, an organization's relative position held within its industry assists in determining whether profitability is either below or above the industry's average. The fundamentality of attaining the above average profitability in the long range is to enable the involved firms attain competitive advantage. Inasmuch as an organization may have a series of weaknesses and strengths, as compared to its rivals, Porter's Model suggests that there are two primary modes of competitive advantage that an organization can possess: image differentiation or low cost. Combining scope activities to the listed main modes of competitive advantage enable organization to accomplish image differentiation strategy. These strategies enable a firm to accomplish a desirable above-average performance in a particular industry.

\subsection{Empirical Literature Review}

Gakuya and Njue (2018), examined the influence of image differentiation on client loyalty amongst pharmaceutical firms operating within Nairobi City County. The findings of the study revealed that image differentiation had positive statistical influence on clientele loyalty among pharmaceutical companies in Nairobi city. It was recommended that pharmaceutical companies need to invest more resources on image differentiation in an effort to maintain customer loyalty.

Ngari (2017) investigated channel differentiation's impact on clientele satisfaction among 42 Kenyan commercial banks. Conclusions made were that differentiation strategies contributed heavily to clientele satisfaction of Kenya commercial banks. It was recommended that Kenyan commercial banks should build the capability of their marketing teams in handling diverse market niches.

Thorough and extensive review of relevant literature facilitated the development of the conceptual framework presented in Figure 1.

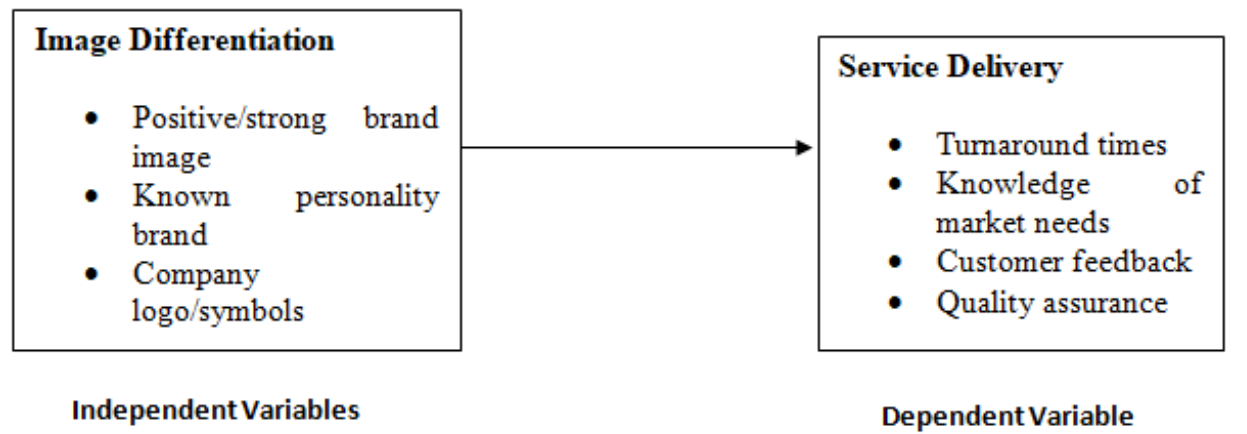

Figure1. Conceptual Framework

Source: Researcher (2019)

On the basis of the conceptual framework, the research hypotheses for this study were;

$\boldsymbol{H}_{\boldsymbol{o}}$ : Image differentiation has no effect on service delivery of insurance firms in Nairobi City County.

$\boldsymbol{H}_{1}$ : Image differentiationaffectsservice delivery of insurance firms in Nairobi City County.

\section{RESEARCH METHODOLOGY}

The study adopted the descriptive survey design. The design results in rich data collected in large amounts. The basis of descriptive research is to discover where, what and how phenomenon of interest came to be (Creswell, 2014). Employing descriptive design provides a researcher with full explanation of applicable features giving from various dimensions of the subject under investigation (Orodho \& Kombo, 2002). As per Bryman (2016) notes that descriptive research design is essential in enabling the study to utilize the preliminary studies and exploratory research and allow availing of data based on the current phenomena context. The use of descriptive research design was consistent with past studies by (Thangaru \& Kinyua, 2017; Kimaru \&kinyua, 2018; Mbai, Muhoho \& Kinyua, 2018; Mirugi \& Kinyua, 2018)

The population of the study encompassed of employees from insurance firms in Nairobi City County. The target population for comprised of middle level management, functional level managers and, functional level staff from the selected insurance firms in Nairobi City County, Kenya as shown in table 1 . 
An Empirical Investigation on the Effect of Image Differentiation on Service Delivery of Selected Insurance Firms in Nairobi City County, Kenya

Table1. Distribution of Sample Size

\begin{tabular}{|l|l|l|l|l|}
\hline Strata & Target population & Sampling Factor \% & Sample Size & Percentage \\
\hline Middle level management & 117 & 0.3 & 35 & 35 \\
\hline Functional level management & 118 & 0.3 & 35 & 35 \\
\hline Functional level Staff & 103 & 0.3 & 30 & 30 \\
\hline Total & $\mathbf{3 3 8}$ & & $\mathbf{1 0 0}$ & $\mathbf{1 0 0}$ \\
\hline
\end{tabular}

Source: Researcher (2019)

A sample size of 100 respondents was selected from the study's target population using stratified random sampling technique. The sampling factor of 0.3 was used according to Mugenda and Mugenda (2013). Middle level management and functional level management had equal input amounting to $35 \%$ from each while the functional level staff input was $30 \%$ of the total input of respondents.

The study utilized primary data, using the structured questionnaires as the tool for data collection. Questionnaire was the preferred tool for the data collection process due to its simple yet effective nature (Bryman, 2016).Questionnaires can collect information from a huge number of respondents over a short time span. Use of structured questions has been widely adopted in empirical studies (kinyua, Njoroge, Wanyoike\&Kiiru, 2015; Kiprotich, Kahuthia\& Kinyua, 2019; Makori\& Kinyua, 2019).

The validity of the instrument was checked by seeking counsel from experts in the field as well as by conducting a review of literature and theories to authenticate content and construct validity of the instrument. Additionally, the consistency of the instrument was tested by conducting a pilot study in insurance companies neighboring Nairobi City County. The Chronbach alpha coefficients were used to assess the internal consistency of the instrument. Results having a Chronbach alpha of 0.7 and above indicate that the instrument has good internal consistency. O'Dwyer\&Bernauer (2014), suggest that an instrument that has Chronbach alpha of above 0.7 is fit for use since it has internal consistency. The use of 0.7 Cronbach alpha coefficient as a threshold has been used in other research studies (Kahuari, Muraguri \& Kinyua, 2019; Mugo, Kahuthia\& Kinyua, 2019; Mutuvi, Muraguri \& Kinyua, 2019). The reliability statistics are displayed in Table 2.

Table2. Results of Reliability Test

\begin{tabular}{|l|l|l|l|}
\hline Research variable & Cronbach alpha index & Number of items & Comments \\
\hline Image Differentiation & 0.800 & 7 & Reliable \\
\hline Service Delivery & 0.855 & 9 & Reliable \\
\hline Aggregate & $\mathbf{0 . 8 1 5 8}$ & $\mathbf{1 6}$ & \\
\hline
\end{tabular}

Source: Pilot Data (2019)

Findings in Table 2 show Cronbach alpha values for Image differentiation and service delivery has of $(\alpha=0.800)$ and $(\alpha=0.855)$ respectively. The aggregate score of Cronbach alpha associated with 16 items related to the two variables is $(\alpha=0.8158)$

The collected data was then filtered, edited and coded by assigning numerical values which helped in reducing the number of errors during the analysis process. The data were analyzed using descriptive statistics and inferential statistics computed in Statistical Package for Social Sciences. Descriptive statistics comprised of frequencies, percentages, mean, standard deviation and coefficient of variation and the results were presented using figures and tables. Inferential statistics applied simple linear regression analysis model 1 presented below.

$\mathrm{Y}=\boldsymbol{\beta}_{0}+\boldsymbol{\beta}_{1} \mathrm{X}+\varepsilon \ldots \ldots \ldots \ldots \ldots \ldots \ldots$............... 1

Where;

$\mathbf{Y}=$ Service Delivery

$\mathbf{X}=$ Image Differentiation

$\boldsymbol{\beta}_{0}, \boldsymbol{\beta}_{1}$, = beta coefficients

$\boldsymbol{\varepsilon}=$ Error term 
An Empirical Investigation on the Effect of Image Differentiation on Service Delivery of Selected Insurance Firms in Nairobi City County, Kenya

Simple linear regression analysis was conducted to establish the relationship between corporate communication and performance of Equity Bank Limited, Nairobi City County, Kenya The output was analyzed using the SPSS software. Analysis of Variance (ANOVA) was used to test the statistical significance of the model by indicating the probability of the occurrence of $\mathrm{R}^{2}$. The F-statistic in the ANOVA table was used to measure the fitness of the estimated regression model at $95 \%$ level of confidence where a p-value of at most 0.05 was used as the threshold for making the inference. The pvalues and the t-static for the variables was used to ascertain the statistical significance of the beta coefficients generated in the regression analysis. 0.05 was used as the threshold to establish if the coefficients were statistically significant at the $95 \%$ confidence level.

\section{RESEARCH FINDINGS AND DISCUSSION}

Out of the 100 questionnaires administered, the researcher got back 87 questionnaires. This indicated $87 \%$ response rate, which was high enough to warrant the researcher to proceed with data analysis. As per Mugenda and Mugenda (2013), a 50\% and above response rate is rational to make analysis in social science research.

\subsection{Descriptive Statistics}

Descriptive statistics was conducted by computing standard deviation, mean and coefficient study construct of image differentiation. Descriptive statistics analysis results for service delivery and the independent variable image differentiation statistics is presented in table 3.

Table3. Descriptive Statistics for Image Differentiation

\begin{tabular}{|c|c|c|c|c|c|c|}
\hline Statement & $=$ & $\Xi$ & 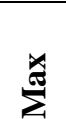 & $\stackrel{\Xi}{\stackrel{\Xi}{\Xi}}$ & ¿் & ن \\
\hline Customers perceive the image of our firm positively. & 87 & 1 & 5 & 4.29 & 0.756 & 18 \\
\hline Company's products and services appeal to customers. & 87 & 1 & 5 & 4.23 & 0.649 & 15 \\
\hline There is constant development of distinctimage. & 87 & 2 & 5 & 3.90 & 0.759 & 19 \\
\hline There is a built and established personality brand. & 99 & 2 & 5 & 3.82 & 0.761 & 20 \\
\hline Performance is influenced by the company's image & 87 & 2 & 5 & 4.18 & 0.845 & 20 \\
\hline $\begin{array}{l}\text { Advertising and communication shapes the image of the } \\
\text { company. }\end{array}$ & 87 & 1 & 5 & 3.93 & 0.817 & 21 \\
\hline $\begin{array}{l}\text { Good reputation has aided service delivery of the company in } \\
\text { the last five years. }\end{array}$ & 87 & 1 & 5 & 4.15 & 0.854 & 20 \\
\hline Average & & & & 4.13 & 0.732 & 17 \\
\hline
\end{tabular}

Source: Field Data (2019)

From the table, the average mean for image differentiation was 4.13 , with the average standard deviation and covariance of variation being 0.732 and $17 \%$ respectively. The mean values for the statements that were being assessed ranged from 3.82 being the lowest mean and 4.29 as the highest mean. In the same breadth, the standard variations of the statements ranged between 0.649 and 0.854 , and the coefficient of variation having the highest value as $21 \%$ and the lowest coefficient being $15 \%$, which showed the statements had a low variation relative to the means of image differentiation measures. This narrow variation proved the mean being steady enough to be relied upon to estimate population mean. These results prove that image differentiation was being practiced by the insurance firm and was a key element in the service delivery of the selected insurance firms in Nairobi City County, Kenya.

Table4. Descriptive Statistics for Service Delivery

\begin{tabular}{|c|c|c|c|c|c|c|}
\hline Statements & $\Xi$ & $\sum . \equiv$ & $\sum \frac{x}{\sigma}$ & Mean & 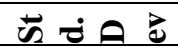 & $\dot{v}>$ \\
\hline $\begin{array}{l}\text { There is a fast turnaround times for service delivery, } \\
\text { which motivates clients }\end{array}$ & 87 & 1 & 5 & 4.37 & 0.677 & 15 \\
\hline $\begin{array}{l}\text { The firm ensures customers have full knowledge of } \\
\text { its products and services. }\end{array}$ & 87 & 1 & 5 & 3.85 & 0.719 & 18 \\
\hline $\begin{array}{l}\text { All employees have full knowledge of the market } \\
\text { needs, and strive to meet them adequately. }\end{array}$ & 87 & 1 & 5 & 3.85 & 0.719 & 20 \\
\hline $\begin{array}{l}\text { Customer feedback help improve on service delivery } \\
\text { to existing and potential clientele. }\end{array}$ & 87 & 1 & 5 & 4.42 & 0.792 & 18 \\
\hline
\end{tabular}


An Empirical Investigation on the Effect of Image Differentiation on Service Delivery of Selected Insurance Firms in Nairobi City County, Kenya

\begin{tabular}{|l|l|l|l|l|l|l|l|}
\hline $\begin{array}{l}\text { Customer suggestion boxes where customers can } \\
\text { comfortably drop their complains and suggestions }\end{array}$ & 87 & 1 & 5 & 3.91 & 0.776 & 19 \\
\hline $\begin{array}{l}\text { There is room for online customer reviews for online } \\
\text { services. }\end{array}$ & 87 & 1 & 5 & 3.68 & 0.640 & 17 \\
\hline $\begin{array}{l}\text { The firm responds very fast to customer needs on } \\
\text { time. }\end{array}$ & 87 & 1 & 5 & 4.06 & 0.758 & 19 \\
\hline $\begin{array}{l}\text { Clients are always assured of quality service every } \\
\text { time. }\end{array}$ & 87 & 1 & 5 & 4.16 & 0.808 & 19 \\
\hline $\begin{array}{l}\text { There are efforts being made to be reliable to our } \\
\text { clients. }\end{array}$ & 87 & 2 & 5 & 4.35 & 0.716 & 16 \\
\hline Average & & & & 4.27 & 0.737 & 17 \\
\hline
\end{tabular}

Source: Field Data (2019)

The results presented in table 4, the average mean for service delivery of the selected insurance firms in Nairobi City County, Kenya, was 4.27, average standard deviation was 0.737 and the average coefficient of variation was $17 \%$. The statements had the highest mean as 4.37 and the lowest at 3.68. On top of that, the range of the standard deviations were between 0.640 and 0.808 while that of the variation being between $15 \%$ and $20 \%$. The narrow variation indicate that the responses did not vary much and the mean could be used to predict the mean of the population and to make generalization.

\subsection{Inferential Statistics}

A simple linear regression analysis was run to expose the effect that image differentiation had on service delivery of selected insurance firms in Nairobi City County, Kenya. Table 5 present regression analysis results.

Table5. Correlation Analysis Results

\begin{tabular}{|l|l|l|l|}
\hline \multicolumn{2}{|l|}{ Service Delivery } & Service Delivery & Image Differentiation \\
& Pearson Correlation & 1 & $.746^{* *}$ \\
& Sig. (2-tailed) & & .000 \\
& $\mathrm{~N}$ & 87 & 100 \\
\hline & Pearson Correlation & $.746^{* *}$ & 1 \\
Image & Sig. (2-tailed) & .000 & \\
Differentiation & $\mathrm{N}$ & 87 & 100 \\
\hline
\end{tabular}

Correlation is significant at the 0.01 level (2-tailed)

Independent variables: Image differentiation

Dependent variable: Service Delivery (SD)

Source: Survey (2029)

As seen from the findings presented in table 5, image differentiation was both positive and significantly correlated to service delivery. This was supported with $\mathrm{r}=0.746, \mathrm{p}=0.000$, and $\alpha=$ 0.01 . Therefore, it is evident that image differentiation was an important strategy in improving service delivery. These findings are parallel with the findings by Chiguvi and Tadu (2020), which concluded image differentiation was crucial in gaining competitive advantage in Botswana's tertiary institutions. Private tertiary education institutions in Botswana.

Table6. Regression Analysis Results

\begin{tabular}{|c|c|c|c|c|c|c|c|}
\hline \multirow[t]{2}{*}{ Model } & & & \multicolumn{2}{|c|}{$\begin{array}{l}\text { Unstandardized } \\
\text { Coefficients }\end{array}$} & \multirow{2}{*}{\begin{tabular}{|l|} 
Standardized \\
Coefficients \\
Beta
\end{tabular}} & d & \multirow[t]{2}{*}{ Sig. } \\
\hline & & & $\mathrm{B}$ & Std. Error & & & \\
\hline \multirow{6}{*}{1} & (Constant) & & 1.324 & .310 & & 2.166 & .033 \\
\hline & Image differ & entiation & .264 & .087 & 232 & 3.047 & .003 \\
\hline & & $\mathbf{R}$ & & Square & \begin{tabular}{|l|} 
Adjusted \\
Square
\end{tabular} & Std. Error & the Estimate \\
\hline & & $.879^{\mathrm{a}}$ & & 73 & .763 & .31329 & \\
\hline & \multicolumn{4}{|c|}{\begin{tabular}{|l|l|} 
Sum of Squares & $\mathrm{df}$ \\
\end{tabular}} & Mean Square & \begin{tabular}{l|l} 
& $F$ \\
\end{tabular} & Sig. \\
\hline & Regression & 3.699 & & 4 & 7.925 & 8.742 & $.000^{\mathrm{b}}$ \\
\hline
\end{tabular}


An Empirical Investigation on the Effect of Image Differentiation on Service Delivery of Selected Insurance Firms in Nairobi City County, Kenya

\begin{tabular}{|l|l|l|l|l|l|l|}
\hline & Residual & 9.324 & 82 & .098 & & \\
\cline { 2 - 4 } & Total & 6.023 & 86 & & & \\
\hline
\end{tabular}

a. Predictors: (Constant), Image Differentiation

b. Dependent Variable: Service Delivery

Source: Field Data (2019)

The regression model 2 below was estimated through the results of regression analysis as shown in Table 5.

\section{Service delivery $=1.324+0.264$ Image differentiation.........Model 2}

The results on the table show that $\mathrm{R}^{2}=0.773$ meaning that $77.3 \%$ of service delivery of the selected insurance firms in Nairobi City County can be influenced by the predictor variable (image differentiation). The table shows the significance level being 0.000 which is lower than $\alpha=0.05$, the significance of the ANOVA model was 0.000 , with its $\mathrm{F}$ value being 8.742 . The results therefore express that statistically, image differentiation had an effect on service delivery.

The researcher aimed to investigate the effect of image differentiation on service delivery. The results of the model explain that image differentiation's effect on service delivery was positive and statistically significant. It had $\beta_{2}=0.264, \mathrm{t}=3.047, \mathrm{p}=0.003$ and $\alpha=0.05$. The findings explain that when management of the insurance companies improve on image differentiation by a single unit, service delivery of the insurance firms increases by 0.264 units.

The findings are corresponding with the findings by Gakuyu and Njue (2018), which showed that image differentiation had a positive statistical influence on clientele loyalty amongst pharmaceutical firms. Additionally, the dissonance theory support these findings and the image differentiation strategy as it shows the post-evaluation of companies which allows the firms to know how their image is perceived by clients.

\section{CONCLUSION AND RECOMMENDATIONS}

Results showed that image differentiation had a significant effect on service delivery of the selected insurance firms in Nairobi City County, Kenya. The correlation between image differentiation and service delivery was positive and significant, it was therefore concluded that image differentiation (positive brand image, known personality brand, company logo) had a significant effect on service delivery. Conclusion that companies should therefore strive to ensure that their clients develop a positive and long-lasting image of their company was made. Companies need to develop logos that are creative and unique so as to interest the clients.

More so, relationship between image differentiation and service delivery was significant, therefore, management of insurance companies should strongly encourage practice of image differentiation. They should ensure that their objectives match the services which they offer on ground. Efforts should also be made to make sure they keep in touch with client's perception of them, by conducting regular surveys and encouraging client feedback, as this will enable them make necessary adjustments to improve how clients perceive them. Investments should be made to improve the advertising efforts to demonstrate the services offered.

\subsection{Recommendations for Further Research}

Focus of the study was on effect of image differentiation on service delivery of among selected insurance companies in Nairobi City County, Kenya. Future researchers should look into other firms and industries and different geographical scope as the current study based its focus on selected insurance companies and the results only apply to the companies in Nairobi City County.

\section{REFERENCES}

[1] AKI Report (2017). Insurance Industry reporters: Association of Kenya Insurers.

[2] Alabar, T. Timothy, Ode Egena, \& Gbande, I. Richard (2014). Service Quality and Customer Satisfaction in Nigerian Mobile Telephony. European American Journal, 37-49.

[3] American Customer Satisfaction Index (2014), http://www.theacsi.org/customer-satisfactionbench marks/benchmarks-by-industry 
An Empirical Investigation on the Effect of Image Differentiation on Service Delivery of Selected Insurance Firms in Nairobi City County, Kenya

[4] Al Khattab, Suleiman \& Aldehayyat, Jehad. (2014). Perceptions of Service Quality in Jordanian Hotels. International Journal of Business and Management, 6, 226-233.

[5] Atikiya, R., Elegwa, E., \&Waiganjo, E. (2015). Effect of Differentiation Strategy on the Performance of Manufacturing Firms in Kenya. Asian Journal of Humanities and Social Studies, 3(2).

[6] Adesoga, A. \& Adeniran, J. (2019). Channel Strategy and Marketing Performance of Selected Consumer Goods Firms in Lagos State, Nigeria. Academy of Marketing Studies Journal, 23(1).

[7] Bryman Alan. (2016). Social Research Methods. Oxford: Oxford University Press.

[8] Creswell, R. (2014). Research design: qualitative, quantitative, and mixed methods

[9] Farshid, M.M., \& Amir, F. (2014). The influence of Marketing Strategy Elements on market share of firms. International Journal on Market fundamental Psychology and Social Sciences. IJ FPSS, 2(1), 19-24.

[10] Gakuya, R.W \&Njue, N. K. (2018). Effects of Differentiation Strategy on Customer Loyalty among Pharmaceutical Companies in Nairobi County, Kenya. European Journal of Management and Marketing Studies, 3(2), 5-9.

[11] Insurance Institute of Kenya (2018). Insurance Institute of Kenya

[12] Kimaru, I. W., \& Kinyua, G. (2018). Relationship between Financial Resources and Performance of Credit Only Microfinance Institutions in Kenya. International Journal of Innovative Research and Advanced Studies, 5(11), 1-6.

[13] Kinyua, G. M., Njoroge, J. G., Wanyoike, R. W., \&Kiiru, D. M. (2015). Influence of Organization's Structure and Culture on Implementation of Strategies in Constituency Development Fund Board in Kenya. International Journal of Education and Research, 3(11), 209-218.

[14] Kiprotich, S. W., Kahuhia, J., \& Kinyua, G. (2019). An assessment of empirical rational strategy and normative re-educative strategy on organizational performance in public offices in Kenya: A case of Teachers Service Commission. International Academic Journal of Human Resource and Business Administration, 3(6), 93-117.

[15] Kiragu, S. M. (2014). Assessment of challenges facing insurance companies in building competitive advantage in Kenya: A survey of insurance firms. International Journal of Social Sciences and Entrepren eurship, 1 (11), 467-490.

[16] Kitur, T., \& Kinyua, G. M. (2020). An Empirical Analysis of the Relationship between Resource Fluidity and Firm Performance: A Perspective of Tours and Travel Companies in Kenya. International Journal of Innovative Research and Advanced Studies, 7(11), 13-21.

[17] Lodorfos, G. Kostopoulos, I. \&Kaminakis, K. (2015). The impact of service delivery system effectiveness on service quality: A hierarchical approach. International Journal of Business Performance Management, 16.

[18] Makanyeza, C.,Kwandayi, P.H \&Ikobe, N. B. (2013). Strategies to improve service delivery in local authorities. International Journal of Information Technology and Business Management, 15(1), 3-6.

[19] Makori, B. N., \& Kinyua, G. (2019). Organizational Leadership and performance of Co-operative Bank of Kenya. International Academic Journal of Human Resource and Business Administration, 3(5), 357-375.

[20] Michael. (2015). How to Create a Differentiation Strategy Based on Superior Service. Retrieved from: http://branduniq.com/2011/how-to-create-a-differentiationstrategy-based-on-superior-service/

[21] Mirugi, T., \& Kinyua, G. M. (2018). Analysis of the Effect of Block Ownership on Performance of Listed Commercial Banks in Nairobi County, Kenya. The Strategic Journal of Business and Change Management, 5(4), 62180-2188.

[22] Mugenda, \& Mugenda A. (2013) Research methods \& quantitative and qualitative Approaches. Kenya African Centre for technologies studies. Nairobi.

[23] Ong'ong'a, N.A. (2014). Effect of marketing strategies in gaining market share by insurance companies in Kenya. Unpublished MBA thesis, University of Nairobi

[24] Thangaru, M. W., \& Kinyua, G. M. (2017). Influence of Organizational Competence on Corporate Governance Practices in National Industrial Training Authority. International Journal of Education and Research, 5(3), 83-9

\section{AUTHORS' BIOGRAPHY}

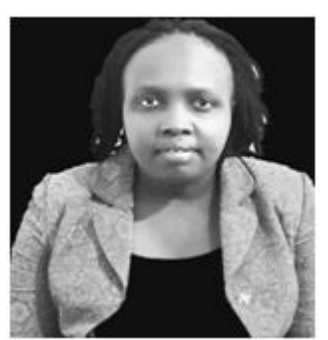

Benadette Kemboi Kiprono, is an accomplished Insurance Professional. She holds a Diploma from the Chartered Insurance Institute in London, she holds a Degree of Business Administration from Kenya Methodist University, Kenya, currently pursuing a Degree in Master of Business Administration in Strategic Management from Kenyatta University, Kenya. My key areas of interest in research is service delivery as a competitive edge in Insurance industry. I have vast experience in Insurance basically in risk assessment and pricing, strategic 
An Empirical Investigation on the Effect of Image Differentiation on Service Delivery of Selected Insurance Firms in Nairobi City County, Kenya

management process, research $\&$ innovation and expertise in operations management.

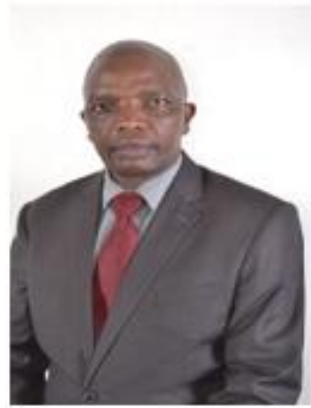

Dr. Godfrey M. Kinyua, is a lecturer in the department of Business Administration, school of Business of Kenyatta University. He holds a Doctor of Philosophy in Business Administration from Kenyatta University, Master of Business Administration from the University of Nairobi and Bachelor of Education from Egerton University. His key areas of interest in research includes knowledge management, competitive intelligence and green innovation.

Citation: Benadette Kemboi Kiprono, Godfrey Muigai Kinyua. "An Empirical Investigation on the Effect of Image Differentiation on Service Delivery of Selected Insurance Firms in Nairobi City County, Kenya" International Journal of Managerial Studies and Research (IJMSR), vol 9, no. 6, 2021, pp. 39-47. doi: https://doi.org/10.20431/2349-0349.0906005.

Copyright: () 2021 Authors. This is an open-access article distributed under the terms of the Creative Commons Attribution License, which permits unrestricted use, distribution, and reproduction in any medium, provided the original author and source are credited. 